\title{
THE MEANING OF CREATIVE ECONOMY IN THE MINANGKABU COMMUNITY IN THE WEST SUMATRA TOURISM DESTINATION AREA, INDONESIA
}

\author{
ZUSMELIA* \\ Sociology Education Study Program, STKIP PGRI West Sumatra, \\ Jl. Gn. Pangilun, Gn. Pangilun, Kec. Padang Utara, Kota Padang, Sumatera Barat, Indonesia, e-mail: zusmelia_2002@yahoo.com \\ IRWAN \\ Sociology Education Study Program, STKIP PGRI West Sumatra, \\ Jl. Gn. Pangilun, Gn. Pangilun, Kec. Padang Utara, Kota Padang, Sumatera Barat, Indonesia, e-mail:irwan7001@gmail.com
}

Yossi E. PUTRI

Economics Education Study Program, STKIP PGRI West Sumatra,

Jl. Gn. Pangilun, Gn. Pangilun, Kec. Padang Utara, Kota Padang, Sumatera Barat, Indonesia, e-mail:yosiekaputri4051@gmail.com

\section{Nilmadesri ROSYA}

Economics Education Study Program, STKIP PGRI West Sumatra,

J1. Gn. Pangilun, Gn. Pangilun, Kec. Padang Utara, Kota Padang, Sumatera Barat, Indonesia, e-mail: nilmadesrirosya@gamil.com

\section{Felia SISKA}

History Education Study Program, STKIP PGRI West Sumatra,

Jl. Gn. Pangilun, Gn. Pangilun, Kec. Padang Utara, Kota Padang, Sumatera Barat, Indonesia, e-mail:faliasiska17@gmail.com

\begin{abstract}
Citation: Zusmelia, Irwan, Putri, Y.E., Rosya, N., \& Siska, F. (2020 THE MEANING OF CREATIVE ECONOMY IN THE MINANGKABU COMMUNITY IN THE WEST SUMATRA TOURISM DESTINATION AREA, INDONESIA. GeoJournal of Tourism and Geosites, 33(4spl), 1551-1556. https://doi.org/10.30892/gtg.334spl16-607
\end{abstract}

\begin{abstract}
The aim of this project was to analyze the meaning of the creative economy in the Minangkabau community in the tourist destination area of West Sumatra. This research uses a descriptive qualitative approach. This research was from the province of West Sumatra. Data collection by observation, Focus Group Discussion (FGD), and in-depth interviews. The results showed that the creative economy had created economic added value, increased tourism, and strengthened local culture. Economic actors' actions in tourist destination areas prioritize rational economic actions and do not consider economic motives. The creative economy is not influenced by local habits or culture in taking action so that economic actors prioritize earning profits. The meaning of the Minangkabau community's creative economy in the tourist destination area is action prioritizing profit, action-oriented towards prospects, the action being accessible to all levels, action prioritizing opportunities, and actions have attractiveness and habits. It is shown that these creative economic actions tend to ignore the socio-cultural elements of local products. Cultural values drive the development of the creative industry in West Sumatra. The attractiveness and habits of local touris ts and tourists from mancanagara (foreign tourists) become capital and action in the creative economy.
\end{abstract}

Key words: meaning of creative economy, Minangkabau community, tourist destinations.

\section{INTRODUCTION}

Indonesia is to enjoy the demographic bonus era in 2020-2035 (BPS, 2018). The population of productive age is estimated to reach 64 percent of Indonesia's total population of 297 million. It can positively impact Indonesia's regions if the demographic bonus to an acceleration of development in Indonesia. On the other hand, it will negatively impact if Indonesian people's quality is not adequate. Through its sixteen creative industry sub-sectors, the creative industry has an essential role in Indonesia's future economy. Based on the results of research between the Creative Economy Agency (Bekraf) and the Central Statistics Agency (BPS) in 2016, it is noted that the creative economy contributed to the national economic growth of 922.59 billion rupiahs or 7.44 percent of the national Gross Domestic Product (GDP). Much empirical evidence supports that the creative industry impacts GDP through the creative industry sub-sector and creates a new form of cultural industry governance (Fahmi et al., 2016; Daubaraite and Startiene 2015; United Nations Development Program 2013).

The craft, culinary, fashion, and handicraft sectors are the subsectors that provide the highest added value contribution (Gary 2016: 1). In the 2010-2015 period, the amount of creative economy GDP increased from 525.96 trillion rupiahs to 852.24 trillion rupiahs, increasing about $10.14 \%$ per year in the creative economy GDP. The average export growth of the creative economy was $7.1 \%$, and the average contribution of the added value of the creative economy to total GDP was 7.13\% (Gary 2016). The results of the analys is by BPS and Bekraf reveal that the creative economy has not grown evenly. BPS noted that in 2016, of the 8.2 million creative economy businesses were still concentrated in Java and could only absorb 16.91 million workers that year. Fahmi et al. (2016) in their research concluded that the creative industry has succeeded in triggering economic growth but has not been centralized in all regions, so it is necessary to group creative industries supported by skilled labor. Daubaraite and Startiene (2015), in their research, found that the creative industry has an impact on creating new jobs by using skills, talents, and creativity so that it has a significant impact on economic growth.

The trend of economic growth in West Sumatra has tended to slow down and even decline over the last ten years, and the GDP per capita is relatively low compared to the surrounding provinces. This condition requires West Sumatra to seek new sources of economic growth under the local economy's character that is approaching an inclusive development posture where the growth achieved can be accompanied by

\footnotetext{
${ }^{*}$ Corresponding author
} 
economic equality captured from the HDI and the West Sumatra Gini ratio. BPS data shows that the industrial sector's contribution only reached $11.36 \%$ in 2014 and decreased to $10.97 \%$ n 2015. This condition leaves some suspicion that the development of the creative industry in West Sumatra still has several problems that hinder this sector's growth. The majority of developing creative ind ustries are micro and small in scale, which is generally limited access. It is assumed that the creative economy's development had not integrated with other economic sectors due to weak support from the supporting system and lack of coordination among related stakeholders. The development of the creative economy and its supporting industries cannot be done partially but must use a holistic and systemic approach.

West Sumatra Province has diverse tourism potential and constitutes the national tourism system. According to Sawirman (2008), tourism objects in West Sumatra have advantages, beauty, uniqueness of customs, art, history, and other natural resources. Tourism developed in West Sumatra is on Islamic rule, which is on the Minangkabau philosophy, namely "Adat with Syara Code, Syara Enc oded in the Book of God" (ABS-SBK). Indirectly, it raises a halal tourism paradigm and gets the best tourism award at the national level, based on the Ministry of Tourism assessment. The potential for tourism in West Sumatra is an attraction that is not only at the national and international levels. The development and socio-economic processes in West Sumatra Province also affect the development and development of the creative economy at the micro-level. In line with Clare's (2013) thinking, the creative economy is an element of regional development and socio-economic improvement. Tourism is one of the most effective solutions to overcome poverty in rural communities (Purnomo, 2020). The creative economy creates economic value-added and local cultural heritage.

It appears based on knowledge or creative ideas from society. Based on the Institute for Economic and Social Research (2005), the creative economy has added value and intellectual property in the form of expertise, talents, interests, and creativity to be come use-value and selling value. Besides, the creative economy is local wisdom that develops in society and becomes a local culture (Azizah, 2017). Moore (2014) states that the creative economy is built on values embedded in place in an area. It means the creative economy is following the unique characteristics of a region. However, the West Sumatra economic actors have not yet made innovations in products, marketing, and technology. Even though the people in West Sumatra are known for their genuine entrepreneurial spirit and social capital, they respected value. West Sumatra tourist destinations are still selling foreign products and non-local content.

It raises that the creative economy in West Sumatra in tourist destinations is still at the theoretical stage and not yet at the experimental stage or traditional value. Based on the problems expressed in the background, the research aims to analyze the meaning of the creative economy in the Minangkabau community in the tourist destination area of West Sumatra.

\section{LITERATURE REVIEW}

\section{Creative Economy: Weber's Social Action}

The relationship between the creative economy as an economic-socio-cultural action has received attention from Weber's thinking as an economic sociologist. The actions taken have a subjective meaning for economic actors in obtaining utility. Social actions carried out by economic actors often prioritize these acts' aims and objectives (Turner and Bryan, 2012; Turner et al., 1998). Weber explained that social action pays attention to other individuals' behavior and is, therefore, directed at a specific goal (Damsar, 2011). Actions are taken by someone related to limited resources by considering the ability, effort, and desire they will achieve to meet the needs of life for goods and services. Actors take these actions to choose actions that aim to maximize the necessities of life. According to Swedberg (1994, 2002), actors' actions are not mere economic actions or phenomena, but economic phenomena that are economically relevant and conditioned. Furthermore, Weber states that social action is real action and has a specific purpose. The social actions taken are always at a rational level. Of course, economic actors have an interest in gaining advantage and competition. Besides, profit and compe tition are always at the desired exchange rate. This understanding refers to the creative economy as a concept to develop local values in an area.

Economic actors in carrying out social actions are obedient and ready to take all risks that must be faced. Creative economy stakeholders emphasize socio-cultural actions in carrying out economic actions, but these actions are interest-driven and rational. It illustrates that the course and the action prioritize expectations of utility value. Weber explained that the economy of action must be in social action. Such action is in economic interest and based on economic considerations when carrying out the social action. Of course, this element exists in economic motives and influenced the habits. Habits form in the form of habits, emotions, and tradition $\mathrm{s}$.

Weber shares social action on four actions: instrumental rationality, value-oriented rationality, traditional or non-rational, and useful. Actions that Weber described as driving aspects of the economy in economic action. Of course, the creative economy built -in prioritizing the interests of economic operators and economic actors. Weber (2006) states that social action is carried out as a direction of ideal and material interests and showed in actor behavior. These two concepts are what distinguish between economic sociology and the new school of economic sociology. According to Weber, ideal interests belong to sociology, and material interests belong to the economy.

It suggests that Weber's social action, as an analysis of the concept of rationality (Kalberg, 1980; Johnson 1990). Creative economic development in developing countries is linked to other development priorities such as poverty alleviation, strengthening local economies (Bocella and Salerno, 2016), and protecting cultural heritage and tourism development (Hesmondhalgh 2012; Towse and Handka 2013; Flew 2013). The creative industry also has an essential role in promoting gender balance. The creative industry, especially in developing countries, can facilitate more excellent absorption of the female workforce (Carter et al., 2013). According to Hawkes (2001), creative industries also tend to be environmentally friendly because they have relatively little dependence on natural resources.

\section{Creative Economy Action}

Creative economy action supports Indonesia's vision of becoming a developed country. The creative economy is to build as a form of sustainable economic development. According to Purnomo (2016), the creative economy tends to create innovation and technological development in the digital era. It encourages and creates new ideas or ideas to continue culture and technology (Azizah et al., 2017). Fahmi et al. (2016) explain that the creative economy mixes contradictory values between new knowledge and cultural values , which are conservative in interpreting the creative economy. There are three main points in the creative economy, namely creativity, to produce something unique and accepted by all levels. Second, innovation, an idea, or ideas by taking advantage of discoveries and producing good products. Third, findings that emphasize the creation of new works that have use and sale value. The creative industry is currently the hope amid the current global economy to boost its share of national GDP.

Since the changefrom an institution that previously joined the Ministry of Tourism and Creative Economy (2009) to become an independent body, namely Bekraf (2015), there are 16 sub-sectors of the creative industry. The sixteen subsectors are architecture; design interior; visual communication design; product design; films, animations, and videos; photography; craft; culinary; music; fa shion; application and game developers; publishing; advertising; television and radio; performing arts; and fine arts. In addition to making a significant contribution to the national economy, the creative industry can also absorb 10.65 percent of the labor force and contribute 5.51 
$\%$ of export value to national exports in 2012. The creative industry believed to be able to answer the challenges of fundamental short and medium-term problems, namely: ( 1) relatively low post-crisis economic growth (on average only 4.5 percent per year); (2) high unemployment rate (9-10 percent); (3) the poverty rate is still high (16-17) percent; and (4) low industrial competitiveness in Indonesia (Kuncoro 2010). The creative economy is part of the integration of knowledge possessed by society with built innovations. This innovation emphasizes the use of technology and culture in action. The creative economy that is built can take advantage of the community's creativity, skills, and talents. President Susilo Bambang Yudhoyono (2007) explains that the creative economy tends to be more towards creativity, culture, or cultural and environmental heritage. Regarding the diversity of creativity, it is technological creativity (invention), the economy of creativity or (entrepreneurship), artistic creativity, and culture (Zusmelia et al., 2020). It needs rephrasing: "It is in line with the thoughts of Zusmelia et al. (2019) 's thoughts that technology is an indicator of economic and socio-cultural improvement in tourist areas in developing the creative economy. It encourages that the creative economy creates added value for economic actors and is based on ideas.

Therefore, the creative economy is primarily based on local knowledge, art, culture, innovation, and technology. Howkins (2001), states that the creative industry is intangible. The creative economy is an economic activity that comes from creativity, talents, and individual skills and can create wealth and create jobs through acquiring and utilizing the intellectual property. Scientists such as John Howkins (Howkins, 2001) and Richard Florida (Florida, 2012) say that now we are in an era of the creative economy where capitalism's transformation takes place from an industrial system based on capital intensive to an industrial system based on ideas and innovations. The Creative Economy Agency (2016) defines the creative economy as a new economic concept that rests on unique ideas, creativity, skills, and talents to create wealth and employment by generating and exploiting individual creative and creative power. The creative economy provides added value because it offers sustainable development through creativity and can contribute significantly to the eco nomy, create a favorable business climate, build national image and identity, increase competitive advantage and provide positive social impacts. The creative economy was born as a holistic concept that deals with the complex interactions between culture, art, economy, and technology. Several kinds of literature provide two opposing views of the value orientation inherent in interpreting the creative economy. The first group is more oriented to the culture-centric side, which emphasizes the community's cultural values, arts, and socio-cultural life.

\section{MATERIALS AND METHODS}

The research was carried out in the province of West Sumatra in the tourist destination of West Sumatra. Areas that include West Sumatra tourist destinations are Padang City, Mentawai Islands Regency, Bukittinggi City, Tanah Datar Regency, and Sawahlunto Regency. The reason for choosing the area was that the area of Padang City, the Mentawai Islands Regency, had represented the typology of coastal communities, and Bukittinggi City, Tanah Datar Regency, Sawahlunto Regency represented the typology of the mainland community. Also, the region has the most fantastic tourist attractions in West Sumatra. This study uses a qualitative approach as the primary approach in analyzing the research objectives. The collecting data technique was carried out by participant observation, in-depth interviews, and Focus Group Discussion (FGD). The technique of determining informants was carried out by purposive sampling, with the number of informants being 53 people. The data analysis stage started from the collection of data that was relevant to the research theme which the selection and simplification of the data were carried out to focus on the research problem (data reduction), then the data was presented in the form of narrative text (data display), then withdrawal conclusion (Miles and Huberman, 2014).

\section{RESULTS AND DISCUSSION}

\section{Creative Economy in the West Sumatra Tourism Destination Area}

The creative economy certainly creates and preserves local culture that can be used as an economic source. The creative economy is carried out with economic activities in skills, knowledge, talents, and potential for economic actors. The creative economy in the West Sumatra tourist destination has not implemented a financial system based on ideas and innovations. This illustrates that tourist destinations are still selling high modern products when compared to local products. The percentage of economic actors who sell local and contemporary products is shown in the following Figure 1.

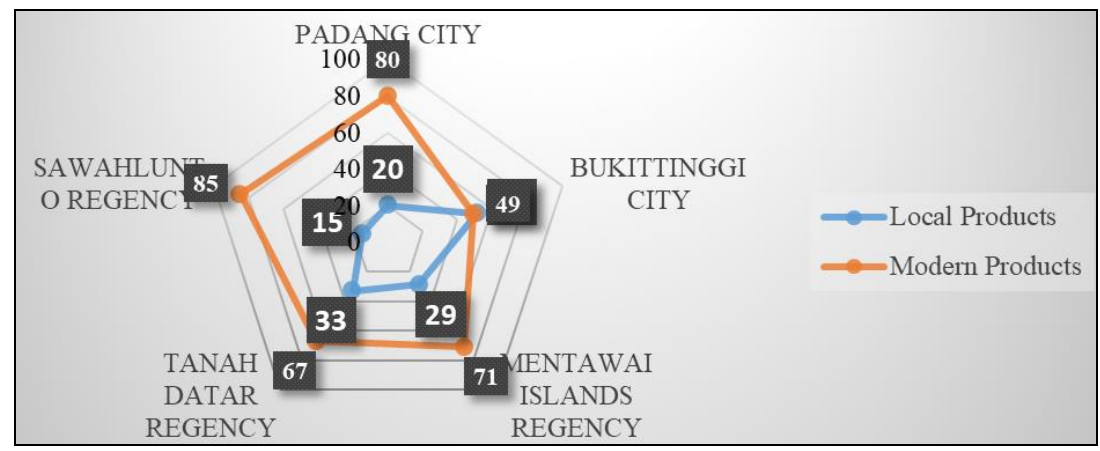

Figure 1. Percentage of Economic Players Selling Products in West Sumatra Tourist Destination Areas

Based on the Figure above, tourist destination areas are still superior in selling foreign products compared to local products. To trained creative economy, West Sumatra's tourist destinations are still taking economic actions based on achieving optimal profits and not based on culture. Howknis (2001) and Florida (2012) explain that the creative economy has led to an economic system based on innovation and ideas. In line with that, the Creative Economy Agency (2016) implements a creative economy that prioritizes ideas, skills, creativity, and talents, thereby creating jobs and increasing people's welfare. However, economic actors in tourist destinations in West Sumatra take rational or profit-based economic actions. Geographically, the creative industries in West Sumatra are spread across almost all districts and cities, but their distribution is not evenly distributed. Creative industries located in rural areas tend to have lower financial inclusion than creative industries in urban areas. The creative economy of tourist destinations can be grouped into four types of business: culinary, fashion, craft (handmade), and performing arts. The percentage of economic actors in tourist destination areas is shown in Figure 2.

Figure 2 shows that the number of traders or sellers is higher in the culinary business than other types of companies. The percentage of creative economy players in the culinary business sector is $68.55 \%$ of the total economic actors in West Sumatra's tourist destination area. The types of fashion and handmade businesses amounted to $13.71 \%$ percent and the art of performing at $4.03 \%$. The culinary 
economy actors' activity is driven by consumer demand, expertise in managing culinary, good business prospects, and sufficient capital. West Sumatra has a unique socio-cultural wealth, making it in a strong position to create a local brand. The development of the creative industry in West Sumatra is driven by cultural values that highlight the culinary, crafts and fashion sub-sectors as the mainstay sectors. The results of this study prove that the creative industry in West Sumatra can facilitate greater absorption of female worker s.

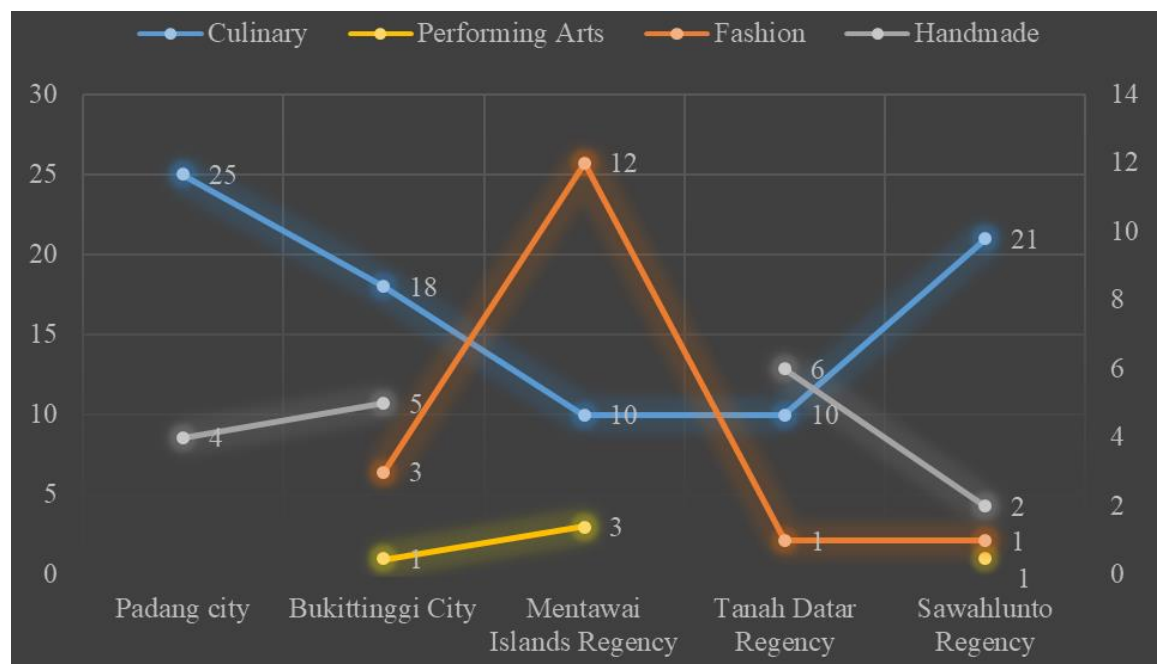

Figure 2. Number of Creative Economy Players by Type of Business in the West Sumatra Tourism Destination Area

These findings reinforce the research of Carter et al. (2013) stated that the creative industry has an important role in prom oting gender balance. The change in taste and consumption patterns of modern society is a challenge for the creative industry in producing products that match consumers' needs and preferences. Export destinations for creative industries are very selective in paying attention to product quality, both in terms of design, material, unique characteristics, etc. The emotional side contained in innovative products is the main attraction for consumers, especially in developed countries. The future challenge is to prepare creative human resources who understand the context of creativity in the creative industry era as a whole. According to Hall (2000), urban growth with high intensity of technological and information advancement can create a conducive environment, especially in terms of the availability of information on banking services that can be utilized. According to Mago and Chitokwindo (2014), better infrastructure in cities can improve banking access for the public and business actors. Florida (2002) researched the factors that shape economic geography through talent and education and their influence on high-tech locations in creative industries and regional development.

\section{The Meaning of Creative Economy for the Minangkabau Community.}

The creative economy action developed by the Minangkabau community is in the form of rational economic action. Rational economic action prioritizes interests and benefits or use value for goods and services. Actions taken by economic actors tend to optimize rational action. The creative economy's application in the tourist destination of West Sumatra considers individual interests above everything else. It does not see the influence of cultural values and social structures that should be promoted or uniquely in the West Sumatra tourist destination. The creative economy actions taken are certainly not submissive and obedient to everything internalized in everyday life in the Minangkabau Society. According to the thoughts of Polanyi et al. (1957); Granovetter (2010); Smelser (2010) explain that the economic activity that has been built is in the undersocialized camp. This thinking is in line with We ber's view that creative economic action in the West Sumatra tourist destination is driven by economic interests and does not consider economic motives. It shows that creative economic action is not influenced by habits, namely habits, feelings, and traditions that are built up in the tourist destination area of West Sumatra. Tracing several tourist objects in Indonesia, such as Pengkalongan, Bandung, and other areas that the creative economy action is built has two considerations: economic action prioritizing cultural considerations and economic activity to achieve optimal profit. Ti illustrates that these actions cannot be separated from the socio-cultural elements of the local community. The creative economy in the West Sumatra tourist destination area is an achievement to earn a living and does not become a model for showing a region's uniqueness. It is built by a formalist economy that is at a profit value.

West Sumatra tourist destinations have several types of businesses: culinary, fashion, handmade, and performing arts. The creative economy in the tourist destination area of West Sumatra is an economic activity inherent in the type of rationality due to rational action. Culinary that is sold by economic actors are more likely to be ready-to-eat culinary or modern food. Economic actors do not prioritize local products as a creative economy. On average, those who sell local products or traditional food in the West Sumatra tourist destination are around $30 \%$. If trace that the creative economy prioritizes local products that develop in an area. This type of creative economy in the form of fashion in the West Sumatra tourist destination sells more modern clothing than local products. It ill ustrates that the creative economy in this fashion business is still minimally sold by economic actors. The percentage who sells fashion in the West Sumatra tourist destination area is around $25 \%$ percent of local products. Suppose we trace that the creative economy prioritizes local values that are innovative. It can develop and become a selling point for the Minangkabau community.

However, the type of fashion business needs to be of economic and cultural value for Ithe development of the creative economy . Besides the types of fashion businesses, there are also types of handicraft businesses developing in West Sumatra Province. Handmade in the West Sumatra tourist destination area is not the main product to be sold as a creative economy. Economic actors are more likely to sell goods from outside rather than local products. If it is traced back to West Sumatra, there are types of local products that can be sold, but very minimal. The percentage who sells local products of the Minangkabau community is around 20 percent. Economic action is only in the realm of individual thought that prioritizes profit. Besides, performing is minimal to become a creative economy in the tourist destination of West Sumatra. West Sumatra tourist destinations play more modern music or bands and play minimal traditional music such as randai, silat, saluting, rabab. The percentage that plays local art performances is around 10 percent, and economic actors prefer modern shows. For to be clearer, the creative economy action analysis model is shown in the following Figure 3. 


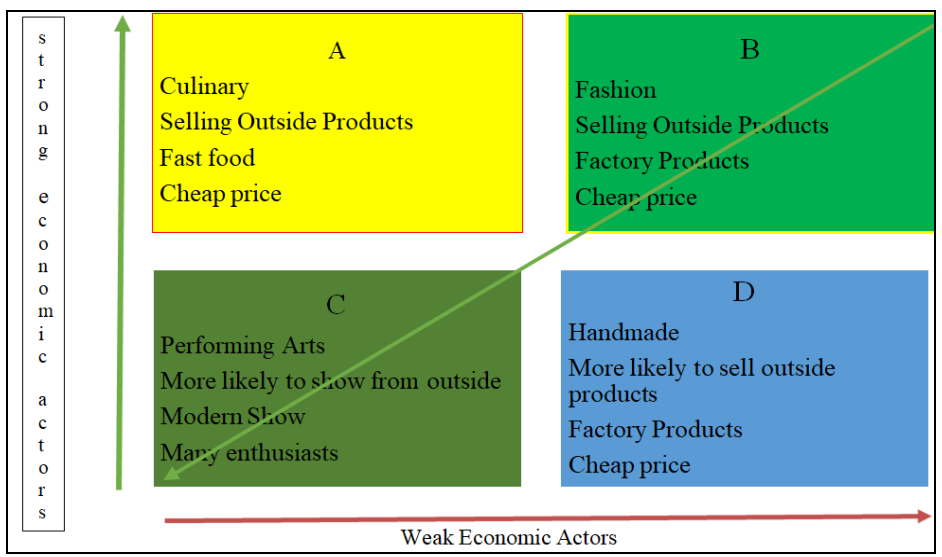

Figure 3. Analysis Model of Creative Economy Actors in West Sumatra Tourist Destination Areas

Based on the Figure Indicate the no. 3, economic actors tend to take financial action above individual interests. They sell products for profit and interest. The ease also drives this in taking action. External products become a mainstay for sale in the tourist destination area of West Sumatra. The stories of economic actors in tourist destination areas have economic rather than non-economic desires. The actions taken are attached to the structure of social networks and social relations for profit. Economic actors decide to sell foreign products because the mindset of economic actors is in rational actors. It is driven by a reflection of the relational and net worked actions inherent in economic actors' actions. The desire of economic actors to sell financial products is due to high opportunities. Besides that, to improve the economy in the household because their work tends to be and is focused on selling or trading. There are several meanings of the creative economy for the Minangkabau community, namely:

\section{Profit First Action}

The Minangkabau community's creative economy in tourist destination areas is associated with benefits in meeting household needs. Those economic actors who sell are more likely to quickly sell branded goods to all social levels, including minimal local goods sold to visitors to tourist attractions. It is encouraged that the Minangkabau people in the tourist destination area prioritize rational thinking and ignore irrational actions. For economic actors, why do they sell if they do not make a profit? The advantage of taking economic action in tourist destination areas is the meaning of the creative economy. Creative industries that grow in regions with high per capita income tend to have a lower proportion of bank credit usage. It can happen if the region has more diverse sources of traditional financing so that the creative industry has many alternative financing options that can be used. Apart from banks, entrepreneurs can also take advantage of other financing alternatives, such as venture capital.

\section{Prospect-Oriented Actions}

Creative economy actors take action, not only do actions but think for prospects that benefit them. This action puts itself into the behavior of others and the environment for thinking of others. Creative economic actors consider use value and can compete during this economic life. It encourages that these actions are not rooted from generation to generation but only for economic gain. The creative economy in the tourist destination area should pay great attention to maintaining traditions and preserving it from generation to generation. However, their actions are only for good prospects for household economic life.

\section{Actions Reach All Layers}

Of course, the products produced are accessible to all levels of society, especially at a price. Tourist destination areas sell local products more expensive than foreign products. It is what encourages the creative economy to be carried out at affordable prices to all levels. The incapacity between capital and income certainly does not get good benefits and prospects for the household economy in the tourist destination of West Sumatra. Price and affordability to all, especially sellers and buyers, are the main factors in developing a tourist attraction.

\section{Opportunity First Action}

The creative economy for the Minangkabau people in the tourist destination area prioritizes opportunities. For them, An opportunity an essential thing in doing business. Which goods are selling well in the market and profit, which becomes their central portion for sale? Opportunities here tend to tourists' tastes and needs, be they local tourists or tourist Pancanagara (foreign tourists). Therefore, the meaning of the Minangkabau people's creative economy in the tourist destination area is to prioritize opportunities for action.

\section{Actions Have Attractiveness and Habit}

West Sumatra has a unique socio-cultural wealth, making it in a strong position to create a local brand. Cultural values drive the development of the creative industry in West Sumatra. The attractiveness and habits of local tourists and tourists from Pancanagara (foreign tourists) become capital and action in the creative economy. For economic actors, goods will not be sold and will profit if they do not sell goods that are the favorite or attraction and habit of the people who visit. The appeal tends to the advertisements on social media, prioritizing modern food. It is the basis that the creative economy has not been sold in destination areas because the attractiveness of the visitors is still modern food or action. The development of the creative economy is practically felt to be following the concept of an inclusive development approach in West Sumatra because it prioritizes the development of innovative human resources compared to the supremacy of capital intensive industries. West Sumatra also has a rich and unique local cultural content that can be explored and used as a starting point for developing the creative economy. The realization of the added value created by innovative economy businesses/companies is expected to accelerate the economic growth of West Sumatra in the future. External financing is an essential factor in developing creative industries (Pasaribu et al., 2007). External funding is needed for companies to expand their business, stimulate investment growth, and build innovation. Inadequate financial conditions can be an obstacle to company growth, especially readiness to face the creative industry market competition, which is dynamic and competitive (Mullineux, 2011; Diallo and Al-titi, 2017). The members of the local community should be engaged in entrepreneurial capacity-building programmes to introduce them to tourism and alternative livelihood options towards enhancing their well-being (Eshun, 2019). 


\section{CONCLUSIONS AND RECOMMENDATIONS}

The creative economy has created economic added value, increased tourism, strengthened local culture. Economic actors' actions in tourist destination areas prioritize Irrational financial efforts and do not consider economic motives. The creative economy is not influenced by local habits or culture in taking action so that economic actors prioritize earning profits. West Sumatra tourist destinations have not implemented an innovative economy, which is the basis for sustainable economic development following government regulations. Creative economy actors carry out financial actions to earn a living in the household and not preserve local culture. The meaning of creative economy in the Minangkabau community in the tourist destination of West Sumatra, is represented by action prioritizing profit, action-oriented to prospects, the action being accessible to all levels, action prioritizing opportunities, and activities have attractiveness and habits. The stories of creative economy actors are economic actions that are only attached to rationality due to the creative economy actors in rational action. The suggestions in this study are (1) the government needs to socialize more intensive economic actors (2) the government needs to facilitate the manufacture of local products so that prices are not too high in the West Sumatra Tourism Destination area and can be reached by the community or tourist visitors (3) economic actors (community) must preserve local culture and not prioritize profit alone.

\section{REFERENCES}

Azizah, S.N., \& Muhfiatun, M. (2018). Pengembangan Ekonomi Kreatif Berbasis Kearifan Lokal Pandanus Handicraft dalam Menghadapi Pasar Modern Perspektif Ekonomi Syariah (Study Case di Pandanus Nusa Sambisari Yogyakarta). Aplikasia: Jurnal Aplikasi Ilmu-ilmu Agama, 17(2), 63-78.

Bocella, S. (2016). Creative economy. Cultural indusry and local development. Social and behavioral science. 223, 291-296. https://doi:10.1016/j.sbspro.2016.05.370

Carter, C., Steiner, L., \& McLaughlin, L. (2013). The Routledge Companion to Media and Gender. Routledge, pp. 21-34.

Clare, K. (2013). The Essential Role of Place Within the Creative Industries: Boundaries, Networks And Play. Citie, $34,52-57$.

Damsar (2011). Introduction to Economic Sociology, Second Edition. Jakarta, Kencana Prenada Media Group.

Daubaraite, U., \& Startiene G. (2015). Creative Industries Impact on National Economy in Regard to Subsectors. Procedia Social and Behavioral Sciences, 213,129-314. https://doi:10.1016/j.sbspro.2015.11.415

Diallo, B., \& Al-Titi, O. (2017). Local Growth and Access to Credit: Theory and Evidence. Journal of Macroeconomics, 1-14.

Eshun, G., \& Tichaawa, T.M. (2019). Reconsidering Participation For Local Community Well-Being In Ecotourism In Ghana. GeoJournal of Tourism and Geosites, 27(4), 1184-1200. https://doi.org/10.30892/gtg.27406-425

Fahmi, F.Z., Hudalah, D., Rahayu, P., \& Woltjer, J. (2014). Extended Urbanization in Small and Medium-sized Cities: The Case of Cirebon, Indonesia Journal Habitat International, 42, 1-10. https://doi:10.1016/j.habitatint.2013.10.003

Fahmi, F.Z., Koster, S., \& Dirk J.V. (2016). The Location of Creative Industries in a Developing Country: The Case of Indonesia. Journalcities, 59, 66-79. https://doi:10.1016/j.cities.2016.06.005

Flew, T. (2013). Global creative industries. Wiley, United States.

Florida, R. (2012). The Rise of the Creative Class, Revisited. New York, Basic Books.

Gary. (2016). The Role of Creative Economy in National Economic Growth. Retrieved from: https://beritagar.id/artikel/infografik/peran-ekonomi-kreatifterhadap-pertumbuhan-ekonomi-nasional

Granovetter, M. (2010). 19 Business Groups and Social Organization. The handbook of economic sociology, 429.

Hall. (2000). Creative cities and economic development. Urban studies, 7, 639-649.

Hesmondhalgh. (2012). Cultural industries and cultural policies. International Journal of Cultural Policy, II, 1-13.

Howkins, J. (2001). The Creative Economy: How People Make Money From Ideas. London, Penguin.

Jon Hawkes. (2001). The fourth pillar of sustainability: Culture's essential role in public planning. Common Ground.

Johnson, D.P. (1988). Teori Sosiologi Klasik dan Modern (Diindonesiakan oleh Robert MZ Lawang). Penerbit PT. Gramedia. Jakarta.

Kalberg, S. (1980). Max Weber's Types of Rationality: Cornerstones for the Analisys of Rationalization Process in History. American Journal of Sociology, 85(5), 1145-1179.

Kuncoro, M. (2010). Visi Indonesia 2030: Quo Vadis? Universitas Gajah Mada. Yogyakarta.

Lenggogeni, S. (2019). Integrated Carrying Capacity of the Marine Tourism Area and Small Island of Mandeh Region and Their Impact on Economic Growth. Economics, $8(1), 35$.

Mago, S., \& Chitokwindo, S. (2014). The impact of mobile banking on financial inclusion in Zimbabwe: A case of Masvingo Province. Mediterranean Journal of Social Sciences, 5 (9).

Miles, M.B., \& Huberman A.M. (2014). Analisis data kualitatif. Penerjemah: Tjetjep Rohendi Rohidi. Jakarta [ID], UI Press.

Moore. (2014). Cultural and Creative Industries Concept- a Historical Perspective. Social and Behavioral Science, $738-746$.

Mullineux, A.W. (2011). Corporate Governance and the "hybridissation" of Financial Sectors. Financial Market Integratioan and Growth. Sprringer, Berlin, Heidelberg, 281-292.

Pasaribu, S., Syaka B, Sejati W.K., Setiyanto A., Hestina J., \& Situmorang J. (2007). Agricultural Sector Financing Policy Analysis. Pusat Analisis Sosial Ekonomi dan Kebijakan Pertanian, Bogor, 65-69.

Purnomo, A., Idris, I., \& Kurniawan, B. (2020). Understanding Local Community in Managing Sustainable Tourism at Baluran National Park - Indonesia. GeoJournal of Tourism and Geosites, 29(2), 508-520. https://doi.org/10.30892/gtg.29210-485

Purnomo, R.A. (2016). Ekonomi Kreatif Pilar Pembangunan Indonesia. Ziyad Visi Media.

Polanyi, K., Arensberg, C. \& dan Pearson, H. (1957). Trade and Market in the Early Empires: Economies in History and Theory. New York, The Free Press.

Sawirman. (2008). Bisnis Pariwisata Sumatera Barat Sebuah Analisis SWOT. Padang, Universitas Andalas, pp. 23-24.

Smelser, N.J., \& Swedberg, R. (2010). The handbook of economic sociology. Princeton university press. pp. 45-76.

Swedberg, R. (1994). Markets as Social Structures. New Jarsey USA, Princeton University Press.

Swedberg, R. (2002). Principles of Economic Sociology. Princeton and Oxford, Princeton University Press.

Towse, R., \& Handka, C. (2013). Handbook on the digital creative economy. Edward Elgar Publishing.

Turner, S., \& dan Bryan. (2012). Teori Sosiologi: Dari Klasik Sampai Posmodren. Yogyakarta, Pustaka Pelajar.

Turner, J.H., Beeghley, L., \& Powers, C.H. (1998). The Emergence of Sociological Theory. Belmont, Wadsworth Publishing Company.

Weber, M. (2006). Etika Protestan dan Spirit Kapitalisme. Yogyakarta, Pustaka Pelajar.

Zusmelia, Ansofino, Yossi, E., \& dan Nilma, D. (2020). Development of Halal Tourism Destinations to Improve Economic Growth. Proceedings of the 2nd Social and Humaniora Research Symposium, (SoRes 2019), 2(2), 412-417.

***Badan Ekonomi Kreatif. (2016). Laporan penyusunan PDB Ekonomi Kreatif 2010-2015.

*** BPS (2017). Laporan Tenaga Kerja Ekonomi Kreatif, Jakarta.

*** BPS (2017). Laporan Ekspor Ekonomi Kreatif, 2010-2016, Jakarta, BPS

*** BPS (2018). Produk Domestik Regional Bruto Provinsi- Provinsi di Indonesia Menurut Lapangan Usaha 2013-2017, Jakarta.

*** BEKRAF (2017). Rencana Strategis Badan Ekonomi Kreatif 2015-2019, Jakarta, Bekraf.

*** Institute for Economic and Social Research. (2005). Roadmap of Indonesian Infrastructure Development (Final Report). Ministry of Education and Culture. Faculty of Economics. Jakarta, University of Indonesia.

*** Republik Indonesia. (2009). Undang-Undang tentang Kepariwisataan Nomor, 10 Tahun 2009.

*** United Nations Development Programme [UNDP]. (2013). Creative Economy Report 2013 Special Edition. New York: UNDP. Retrieved from: http://www.unesco.org/culture/pdf/creative-economy-report-2013.pdf. 